\title{
Results of the Second Phase of the Project on Supplemental Feeding of Vultures in Ustyurt State Nature Reserve in 2018, Kazakhstan
}

\section{ИТОГИ ВТОРОГО ЭТАПА ПРОЕКТА ПО ПОДКОРМКЕ ПТИЦ- ПАДАЛЬЩИКОВ В УСТЮРТСКОМ ГОСУДАРСТВЕННОМ ПРИРОДНОМ ЗАПОВЕДНИКЕ В 2018 Г., КАЗАХСТАН}

\author{
Pestov M.V. (Ecological Center "Dront", Nizhny Novgorod, Russia) \\ Nurmukhambetov Zh.E., Mukhashov A.T. (Ustyurt State Nature Reserve, Zhanaozen, \\ Kazakhstan) \\ Terentyev V.A. (Association for the Conservation of Biodiversity of Kazakhstan, Astana, \\ Kazakhstan) \\ Пестов М.В. (Экологический центр «Дронт», Нижний Новгород, Россия) \\ Нурмухамбетов Ж.Э., Мухашов А.Т. (Устюртский государственный природный \\ заповедник, Жанаозен, Казахстан) \\ Терентьев В.А. (Казахстанская ассоциация сохранения биоразнообразия, Астана, \\ Казахстан)
}

\section{Контакт:}

Марк Пестов

Экологический центр

"Аронт"

603076, Россия

г. Нижний Новгород,

пр. Ленина, А. 44Б,

кв. 52,

тел.: +79049138753

vipera@dront.ru

Жаскайрат

Нурмухамбетов

Устюртский государ-

ственный природный

заповедник, Жанаозен,

Казахстан

zhaskairat-84@mail.ru

Актан Мухашов

Устюртский государ-

ственный природный

заповедник, Жанаозен,

Казахстан

m.aktan@mail.ru

Владимир Терентьев Казахстанская ассоциация сохранения биоразнообразия Астана, Казахстан vladi142000@ yahoo.co.uk

\section{Contact:}

Mark Pestov

Ecological Center

"Dront"

av. Lenina, 44B-52,

Nizhny Novgorod,

Russia, 603076

tel.: +7904913 8753

vipera@dront.ru

\section{Резюме}

В сообшении приводятся Аанные о результатах мониторинга трёх видов падальшиков: чёрный гриср (Aеgуріus monachus), стервятник (Neophron percnopterus) и белоголовый сип (Gyps fulvus) - с использованием прикормочных плошахок и фотоловушек на территории Устюртского государственного природного заповедника в Мангистауской области (Республика Казахстан). Исследования проводились в ходе реамизации второго этапа проекта при подцержке Фонда Руффорда (Rufford Foundation) в 2018 г. На Аанной территории подтверждено гнездование четырёх пар чёрного грисра и лвух пар стервятника. В ходе реачизации проекта впервые в Казахстане были получены фото живого переднеазиатского меопарда (Panthera pardus saxicolor), подтверждающие присутствие Аанного вида в Устюртском заповеднике.

Киючевые слова: хишные птицы, пернатые хишники, птицы-падальшики, стервятник, Neophron percnopterus, чёрный гриср, Aegypius monachus, белоголовый сип, Gyps fulvus, каракал, Caracal caracal, переднеазиатский леопарь, Panthera pardus saxicolor, подкормочные площадки, фотоловушки, Казахстан, Мангистауская область, Устюртский государственный природный заповедник.

Поступима в реАакцию: 16.03.2019 г. Принята к публикации: 15.04.2019 г.

\section{Abstract}

The article highlights new monitoring data on three vulture species: Cinereous Vulture (Aegypius monachus), Egyptian Vulture (Neophron percnopterus) and Griffon Vulture (Gyps fulvus) - on the territory of Ustyurt State Nature Reserve in Kazakhstan, obtained during the second phase of the project on vulture supplementary feeding in 2018. The project is supported by the Rufford Foundation. The data obtained confirmed the numbers of breeding vultures within Ustyurt State Nature Reserve: 4 pairs of Cinereous Vulture and 2 pairs of Egyptian Vultures. During the implementation of the project, camera traps for the first time registered the presence of a Persian leopard (Panthera pardus saxicolor) in the Ustyurt Reserve.

Keywords: birds of prey, raptors, vultures, Egyptian Vulture, Neophron percnopterus, Cinereous Vulture, Eurasian Black Vulture, Aegypius monachus, Griffon Vulture, Gyps fulvus, Caracal, Caracal caracal, Persian leopard, Panthera pardus saxicolor, feeding station, camera trap, Kazakhstan, Mangistau Region, Ustyurt State Nature Reserve.

Received: 16/03/2019. Accepted: 15/04/2019.

DOI: $10.19074 / 1814-8654-2019-38-179-194$

\section{Введение}

На территории Республики Казахстан обитают 5 видов хишных птиц-падаиьшиков (птиц-некросрагов): обыкновенный стервятник (Neophron percnopterus), бородач (Gypaetus barbatus), кумай, или гималайский гриср (Gyps himalayensis), белоголовый сип (Gyps fulvus) и чёрный гриср (Aegypius monachus) (Аементьев, 1951; Гаврин и др., 1962). Согласно сведениям из Красного списка МСОП стервятник имеет статус исчезаюшего вида - Endangered

\section{Introduction}

Five species of vultures occur in Kazakhstan. These include Egyptian Vulture (Neophron percnopterus), Lammergeier (Gypaetus barbatus), Himalayan vulture (Gyps himalayensis), Griffon Vulture (Gyps fulvus) and Cinereous Vulture (Aegypius monachus) (Dementiev, 1951; Gavrin et al., 1962).

Three species of vultures occur in Mangistau Region, which is located in the southwest of Kazakhstan: Egyptian Vulture, Cinereous Vulture and Griffon Vulture (Kar- 
Zhaskayrat

Nurmukhambetov

Ustyurt State Nature

Reserve, Zhanaozen,

Kazakhstan

zhaskairat-84@mail.ru

Mukhashov A.T.

Ustyurt State Nature

Reserve, Zhanaozen,

Kazakhstan

m.aktan@mail.ru

Vladimir Terentyev

Association for the Con-

servation of Biodiversity

of Kazakhstan

Astana, Kazakhstan

vladi142000@

yahoo.co.uk
(EN), бородач, кумай и чёрный гриср имеют статус видов, находяшихся в состоянии, близком к угрожаемому - Near Threatened (NT), и лишь белоголовый сип имеет статус вида, вызываюшего наименьшие опасения - Least Concern (LC) (BirdLife International, 2016a; 2016b; 2016c; 2016d; 2016e). Нa сегодняшний Аень мишь стервятник, бородач и кумай внесены в Красную книгу Республики Казахстан (2010), однако, по мнению специалистов, сип и гриср также остро нужАаются в специальных мерах охраны и должны быть вкиючены в Перечень редких и находяшихся под угрозой исчезновения видов растений и животных (Скляренко и Ар., 2012).

На территории Мангистауской области, расположенной на юго-запаце Казахстана, ранее были отмечены стервятник, чёрный гриср и белоголовый сип (Карякин и Ар., 2004; Левин, Карякин, 2005; Пфесрфер, 2006; Пиахов, 2009; Нурмухамбетов, Бойко, 2009), причём мяя первых Авух видов было Аоказано гнездование (Ковшарь, $\Delta я-$ кин, 1999; Левин, Карякин, 2005; Псресрфер, 2006; Пестов, Нурмухамбетов, 2012; Пестов и Ар., 2017). По предварительным оценкам на территории Мангистау обитают около 30 пар стервятников и несколько пар грисоов (Скияренко и мр., 2012). На территории Устюртского государственного природного заповедника (УГПЗ), расположенного на юге Мангистауской области, количество гнезАяшихся грисров ориентировочно оценивалось в 3-4 пары, стервятников - в 4-8 пар (Пестов, Нурмухамбетов, 2012).

В 2011 г. на территории Устюртского ГПЗ, впервые м^я Мангистау и Устюрта, был отмечен молодой бородач (Пестов, Нурмухамбетов, 2012). Вероятно, эту же птицу наблюдали сотрудники заповедника в 2013-2014 гг.

По мнению специалистов, основной мимитируюший фактор мяя пацамьшиков в Казахстане, в том числе и в Мангистау это месицит кормовой базы в результате резкого снижения поголовья Аомашних и диких копытных животных, особенно - сайгаков (Saiga tatarica) и Ажейранов (Gazella subgutturosa), в последние десятилетия, прошедшие после распада Советского Союза (Скияренко и Ар., 2012; Плахов, 2006; 2009). Кроме того, в Аанном регионе отмечены единичные случаи гибели грисов и стервятников от поражения электрическим током при контакте с воздушными миниями электропередачи средней мошности (Левин, Куркин, 2013; Пестов и Ар., 2015).

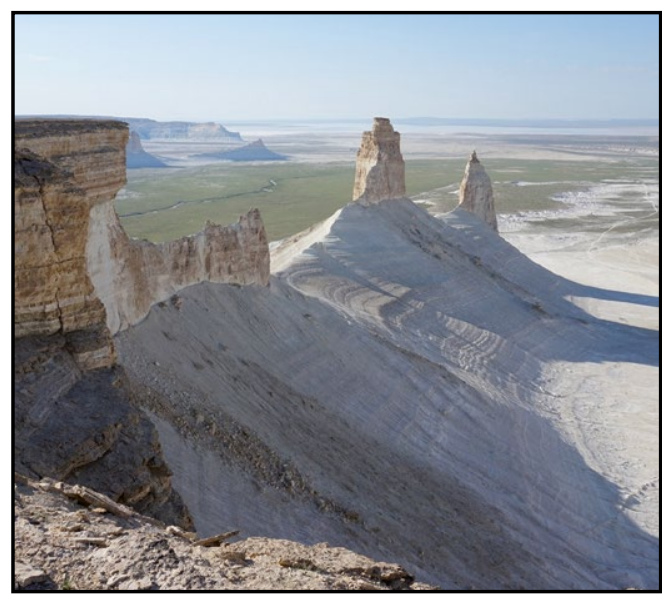

Устюрт. Фото М. Пестова. Ustyurt. Photo by M. Pestov.

yakin et al., 2004; Levin, Karyakin, 2005; Pfeffer, 2006; Plakhov, 2009; Nurmukhambetov, Boyko, 2009). To date, Egyptian Vulture and Cinereous Vulture have been confirmed as breeding species within this area (Kovshar, Dyakin, 1999; Levin, Karyakin, 2005; Pfeffer, 2006; Pestov, Nurmukhambetov, 2012; Pestov et al., 2017).

According to preliminary estimates, there are about 30 pairs of Egyptian Vultures and a few pairs of Cinereous Vultures in Mangistau Region (Sklyarenko et al., 2012). Within the Ustyurt State Nature Reserve, which is located in the Karakiya district in the southern part of Mangistau Region, the number of nesting vultures has been roughly estimated at 3-4 pairs of Cinereous Vultures and 4-8 pairs of Egyptian Vultures (Pestov, Nurmukhambetov, 2012).

According to some experts, the main limiting factor for vultures in Kazakhstan, including Mangistau, is a shortage of food supply caused by the sharp decrease in livestock and wild ungulate populations, especially Saiga (Saiga tatarica) and Goitered Gazelle (Gazella asubgutturosa), in the last decades since the collapse of the Soviet Union (Sklyarenko et al., 2012; Plakhov, 2006; 2009). Besides that, in Mangistau Region there were isolated incidents of electrocution of Cinereous Vultures and Egyptian Vultures on medium voltage power lines (6-10 kV) (Levin, Kurkin, 2013; Pestov et al., 2015).

In 2016 for the first time, our team implemented a pilot project on vulture feeding in the Ustyurt State Nature Reserve with the support of the Rufford Small Grants Foundation $^{44}$ (Pestov et al., 2017). 
Как известно, в ряде европейских стран проведение биотехнических мероприятий, связанных с подкормкой падамьшиков, позволяет подцерживать численность популяций ряла реАКих виАов в условиях десицита кормовой базы (Donazar et al., 2010). На пространстве бывшего СССР аналогичные проекты, связанные с подкормкой падальшиков, ранее были реализованы в Крыму (Костин, Багрикова, 2016) и в Армении ${ }^{\mathbf{4 3}}$.

В 2016 г. впервые мяя Казахстана нами был реализован пилотный проект по подкормке птиц-пахамьшиков на территории УГПЗ при поцмержке Rufford Foundation ${ }^{44}$ (Пестов и мр., 2017). В 2018 г. нами был реализован второй этап Аанного проекта также при поцмержке Rufford Foundation ${ }^{45}$.

\section{Район работ}

Устюртский государственный природный заповедник был создан в 1984 г. на территории Каракиянского района Мангистауской области Республики Казахстан на плошаци 223342 га. По кииматическим условиям регион, гле расположен заповеАник, относится к континентальной южно-туранской пустынной зоне. Главная цель его создания - сохранение в естественном состоянии уникальных природных комплексов, исторических памятников, растительного и животного мира пустынной зоны. Территория заповедника с запада на восток вытянута в самой широкой части на 43 км (от 5409' $\Delta$ о 54 $55^{\circ}$ восточной Аолготы), в меридиональном направлении - на 95 км $\left(42^{\circ} 34^{\prime}-43^{\circ} 23^{\prime}\right.$ северной широты) и вкиючает южную часть Западного чинка плато Устюрт протяжённостью более 120 км, а также примыкаюшую к нему с одной стороны узкую полосу непосредственно плато Устюрт, с Аругой - восточную часть впадины Карынжарык - Кендерли-сор с горой Карамая и небольшой фрагмент песчаного массива Карынжарык. Чинки - это нередко почти отвесные обрывы, ограничиваюшие плато Устюрт, их высота может достигать более 100 м (Плахов, 2006). Именно чинки в сочетании с глубокими каньонами и скалами-останцами определяют неповторимое своеобразие ландшасрта заповедника и являются оптимальным местом Аия гнезАования целого ряда видов хишных птиц, обитаюших в Аанном регионе, в том числе стервятников и грисов.
In 2018, our team completed the second phase of this sponsored project ${ }^{45}$.

\section{Project Location}

Ustyurt State Nature Reserve occupies 223,342 ha and is situated in the Karakiyansky District of the Mangistau Region. The Reserve was established in 1984 and has continental climate conditions of the SouthTuranian arid zone.

Landscape features within the Reserve include the $210 \mathrm{~km}$ stretch of Western "Chink" (chink is a local name for chalk escarpment) of plateau Ustyurt as well as the narrow stretch of the plateau Ustyurt, the eastern part of Karynzharyk depression Kenderli-sor, mount Karamaya and a small section of the sand massif Karynzharyk.

The chinks are often nearly vertical cliffs, which define the plateau Ustyurt. The height of escarpment can reach more than $100 \mathrm{~m}$ (Plakhov, 2006). Escarpment and deep canyons are the primary nesting grounds for the wide range of birds of prey, which occur in the region, including Egyptian Vulture and Cinereous Vulture.

\section{Methods}

From April to November 2018, twice a month our team put out around $20 \mathrm{~kg}$ of offal at each of three feeding stations, which were set up in 2016 (fig. 1). The locations of the stations were selected on the edge of cliffs along the Western "Chink" of the Ustyurt Plateau within the Reserve. During the course of 10 field trips, more than $600 \mathrm{~kg}$ of offal in total was laid out. The offal (stomachs, intestines, lungs, heads and distal limbs of large cattle and camels) was obtained from the slaughterhouse in Zhanaozen.

The first deposition of offal at the feeding stations was performed on 25 April 2018 and the last one on 15 November 2018. Also, in November 2018, outside of the stations, one camera trap was set up on a carcass of the Ustyurt Sheep (Ovis vignei arkal). At each feeding station, two camera traps were set up on $1 \mathrm{~m}$ long metal poles, one able to provide close-up shots at a distance of $1.5-2 \mathrm{~m}$, and the more remote one providing a wider coverage of the site from 3-4 m away.

Before commencing the project in 2016 , we made an official request to the State Committee of Veterinary Control (Ministry of Agriculture of the Republic of Kazakhstan), regarding a use of Diclofenac, a phar-

\footnotetext{
43 http://www.rufford.org/rsg/Projects/MamikonGhasabian

44 http://www.rufford.org/projects/zhaskairat nurmukhambetov

45 https://www.rufford.org/projects/zhaskairat_nurmukhambetov_0
} 


\section{Методика}

С апреля по ноябрь 2018 г. мы с интервалом около Авух недель выкиадываяи примерно по 20 кг мясных субпродуктов на каждой из трёх прикормочных площалок (привах), выбранных нами ешё в 2016 г. (рис. 1). Привады однотипно расположены по краю обрывов Запацного чинка плато Устюрт на территории УГПЗ. Всего за 10 выезАов было выложено около 600 кг субпродуктов (желудки, кишечники, лёгкие, головы и Аистаиьные части конечностей крупного рогатого скота и верблюдов), которые закупамись нами на мясокомбинате в г. Жанаозен и транспортироваиись в пластиковых бочках на территорию заповедника с использованием автомобилей УАЗ. Первая выкиахка субпродуктов на

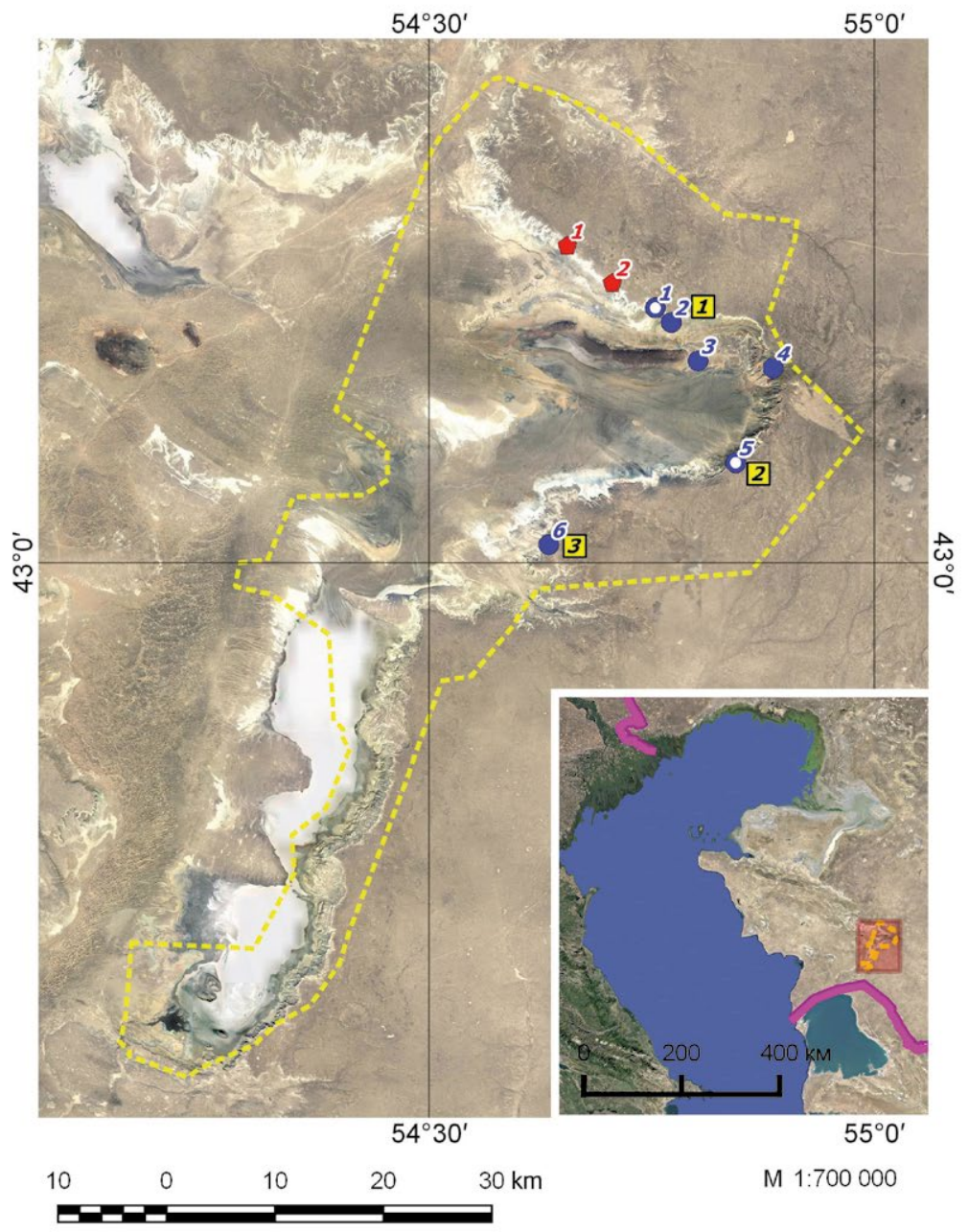

Условные обозначения / Legend:

\footnotetext{
Жилое гнездо чёрного грифа (Aegypius monachus) living nest of the Cinereous Vulture

Не жилое гнездо чёрного грифа (Aegypius monachus) Note living nest of the Cinereous Vulture

Жилое гнездо стервятника (Neophron percnopterus)

living nest of the Egyptian Vulture

Привада (площадка) / feeding station

Граница ГПЗ "Устюртский" / boundaries of the Ustyurt State Nature Reserve
}

maceutical preparation for treating cattle. It was used in a number of Asian countries and was responsible for over $90 \%$ decline of Gyps and Vultures in India, Pakistan and Nepal (see Oaks et al., 2004). The response from the Chairman of this Committee indicated that diclofenac was not registered as a veterinary treatment in the Republic of Kazakhstan, which excluded its use for treatment of cattle.

During spring-summer season 2018, our team conducted extensive field trips to identify nesting locations of vultures. We carried out both road trips and walking surveys along the chinks of the plateau Ustuyrt within the Reserve and outside it. The total distance of the surveys was around $350 \mathrm{~km}$.

\section{Results}

In 2018, when undertaking counting surveys on Donyztau "Chink" at northern part of the plateau Ustuyrt, at least three Cinereous Vultures were observed, probably migrating birds. In the south of Mangistau Region, on Kaplankyr "Chink”, four Egyptian Vultures were counted. Nesting of this species in this area is highly likely, but not yet confirmed. Nesting sites of vultures were found only at the territory of the Reserve: for the first time, nesting was confirmed for Cinereous Vulture, with four pairs (in previous years only 2-3 occupied nests were observed) (fig. 2: 2, 3) and in 2016 - two probable nesting sites of Egyptian Vulture.

On 28 April 2018, the Russian photographers Polonsky E.V. and Chernyshev I.A. observed a group of 7 Griffon Vultures in the northern part of the reserve: at the same time, near the sighting place, no animal carcasses were found (pers. comm.) (fig. 2: 1).

At the active feeding stations, several thousands of photographs were obtained from camera traps. The majority of the photographs were informative and showed the presence of the birds and mammals. Among them, there were multiple photographs of Egyptian Vulture, as well as Cinereous Vulture and Griffon Vulture. The number of different species of vultures observed at the feeding stations in 2016 and in 2018 are presented in table 1.

Рис. 1. Локализация прикормочных площацок (приваА) и выявленных гнёзд птиц-пацамьшиков на территории Устюртского ГПЗ в 2018 г.

Fig. 1. Locations of the feeding station, nests of vultures within the territory of the Ustyurt State Nature Reserve in 2018. 


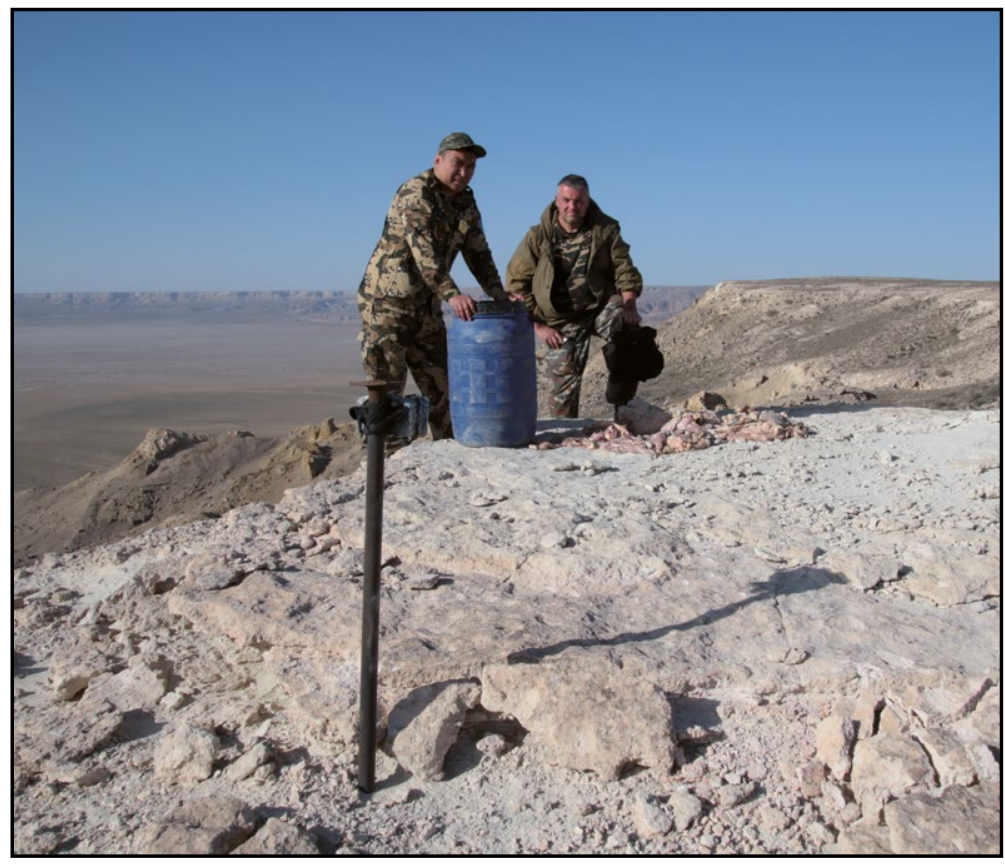

Участники проекта оборудуют привацу № 1. 10.04.2018 г. Фото А. Мухашова.

Project participants are setting up the feeding station $N^{\circ} 1$. 10/04/2018. Photo by A. Mukhashov. посредине между плошалками 2 и 3. привалах была осушествлена 25.04.2018 г., последняя - 15.11.2018 г. Кроме того, в ноябре 2018 г. вне стационарных привах нами была установлена фотоловушка на трупе закаспийского уриала (Ovis vignei arkal), обнаруженного на чинке примерно

На кажАой из плошадок с помошью метамических кольев мииной около 1 м, вбитых в каменистый грунт кувамдой, были установлены по Аве фотоловушки с разных ракурсов и на различном расстоянии от собственно места выкиадки прикормки: 1,5-2 м и 3-4 м, соответственно. Таким образом, "ближняя" ^овушка Аолжна была обеспечить нам крупные планы, "Аальняя" - больший охват территории плошахки и обшие планы на фотограсриях. Все ловушки работали в фото-режиме как в светлое, так и в тёмное время суток, реагируя на появление в радиусе Аействия от 0,1 Ао 5-10 м подвижных объектов размером от мелких воробьиных птиц и крупнее.

Ешё $А$ начаяа реачизации проекта, в 2016 г., нами был слелан осициаиьный запрос в ГУ «Комитет ветеринарного контромя и нацзора" при Министерстве сельского хозяйства Казахстана по поводу применения в Казахстане ветеринарного препарата дикиосренак, который используется в ряде азиатских стран при лечении скота, и, как известно, стаи причиной катастросической массовой гибели пахаиьшиков, приведшей к сокрашению более чем на $90 \%$ популяций нескольких виАов грисров и сипов в Индии, Пакистане и Непале (см. Oaks et al., 2004). Из ответа за подписью пред-
In 2016 and in 2018, the presence of three species of vultures were confirmed by the camera trapping.

\section{Egyptian Vulture (Neophron percnopterus)}

Egyptian Vulture was the most frequent species at the feeding stations both in 2016 and in 2018 (fig. 3: 1, 2, 3). Previously, we estimated the number of this species within the Ustyurt State Nature Reserve as 3-5 nesting pairs (Pestov et al., 2017). In 2018, Egyptian Vultures were observed at all three feeding stations. The maximum attendance was at the station № 2; single vultures attended for 31 days out of 133 days (the time interval between the appearance of the first and last Egyptian Vulture at the station). This corresponds to $27 \%$ of the observation period. The maximum number of birds in one photo was three (two adults and one juvenile), and they were observed at station № 3 . The birds attended exclusively during the daytime between 05:41 am and 08:42 pm. The maximum attendance in one day was about 2 hours and forty minutes (on 01.09.18 two adult birds and one juvenile bird jointly attended the station between 08:57 am till 11:36 am with two breaks of 10-15 minutes). In the majority of cases, adult birds attended the station for 10-20 minutes. The first appearance of the Egyptian Vulture was on 25.04.18 and the last one on 06.09.18. It is worth mentioning that Egyptian Vultures are migrating birds and leave the nesting sites in the autumn (Dementiev, 1951; Gavrin et al. 1962). The total attendance of the Egyptian Vulture at all feeding stations in 2018 was 58 camera trap-days for the entire time of the species' presence at feeding stations (44\%). At all stations, at least two adults and two juveniles were present.

\section{Cinereous Vulture \\ (Aegypius monachus)}

In 2016, one Cinereous Vulture was observed at station № 1 , when it attended the station twice. We obtained nearly 70 photographs of the bird at the station; however, none of them showed the vulture eating offal. This low attendance at the station by the vulture ( 2 days out of 210 days of observation- which is $1 \%$ of the observation period), is probably related to the narrow feeding preferences. Unlike Egyptian Vultures and Griffon Vultures, Cinereous Vultures prefer meat and skin of dead animals (Dementiev, 1951).

From April to October 2018, Cinereous Vulture failed to appear at any of the stations, 
седателя данного комитета следует, что препарат Аикиофенак не зарегистрирован в государственном реестре ветеринарных препаратов Казахстана, что искиючает его использование при лечении сельскохозяйственных животных. Таким образом, начиная наш проект по подкормке, мы были уверены, что наши действия заведомо не могут стать причиной отравления падаиьшиков Аикиофенаком.

С целью выявления фактов гнездования пацаиьшиков на территории Мангистауской области за пределами Устюртского ГПЗ нами было проведено анкетирование целевых групп населения: инспекторов особо охраняемых природных территорий, территориальной инспекции и членов областного обшества охотников. Всего было распространено 80 анкет. К сожалению, никакой значимой информации в ходе анкетирования получить не удалось.

Поиск мест гнездования пацаиьшиков осушествлялся в весенне-летний периол 2018 г. на автомобильных и пеших маршрутах по чинкам плато Устюрт, как на территории Устюртского ГПЗ, так и за её пределами. В том числе были обследованы чинк Капланкыр (южная оконечность плато Устюрт) вблизи государственной границы Казахстана и Туркменистана - около 50 км, участок чинка $\Delta$ онызтау (северная оконечность плато Устюрт) вблизи границ Мангистауской, Атырауской и Актюбинской областей Казахстана - около 50 км и значительная часть Западного чинка, в том числе около 190 км - на территории УГПЗ и около 60 км - за её прелелами. Обшая протяжённость маршрутов составила окомо 350 км. Поиск возможных мест гнезАования и самих хишных птиц проводили путём визуаиьного осмотра чинков с помошью современной оптики (бинокиь БПЦ $12 \times 50$ и подзорная труба 20×60).

\section{Результаты}

В 2018 г. в ходе проведения маршрутных учётов на чинке $\triangle$ онызтау на $\mathrm{Ce}$ верном Устюрте в скоплении степных орлов (Aquila nipalensis) были отмечены не менее 3 чёрных грисров - вероятно, кочуюшие негнездяшиеся особи. На юге Мангистауской области на чинке Капланкыр были отмечены 4 особи стервятника - гнездование этого вила здесь весьма вероятно, но пока не подтверждено. Места гнездования пацаиьшиков были выявлены мишь на территории УГПЗ. При проверке пяти ранее известных нам гнёзд грисра на трёх были обнаружены насиживаю- despite the presence of four nesting pairs within the Ustyurt State Nature Reserve. The last portion of offal at station № 3 was provided on 15.11.2018 and also contained a cow's embryo $80 \mathrm{~cm}$ long. This feed attracted one Cinereous Vulture on 21.11.2018 at 12:48 pm followed by another bird four minutes later. Both birds stayed at the station until 02:04 pm. They actively fed on the embryo and sometimes fought over the feed (fig. 3: 5, 6). A third vulture was also noted approaching although it did not stay. The total attendance of the Cinereous Vulture at the feeding stations in 2018 was less than $0.5 \%$ ( 1 day out of 220 days of the observation). One more Cinereous Vulture was observed for 25 minutes (fig. 4), on 16 November 2018 feeding on Ustyurt sheep remains outside of the feeding station.

\section{Griffon Vulture (Gyps fulvus)}

In 2016, a Griffon Vulture was photographed at the station № 1 during the day hours over four days (near $2 \%$ of total observation period). The photographs showed the vulture eating offal (Pestov et al., 2017). In 2018, the vulture was observed only once on 7 June from 12:17 am until 12:23 am at the station № 2 (fig. 3: 4). The bird did not feed on offal. Fairly low attendance of the feeding stations by Griffon Vultures was broadly in line with its status of rare, vagrant and non-breeding species in this area.

\section{Other species of birds and mammals}

Aside from vultures, camera traps captured another two bird species attracted by the feed: Steppe Eagle (Aquila nipalensis) (fig. 5: 1) - one ind. in the photo was captured on one occasion at the feeding station № 1, and Raven (Corvus corax) - up to 7 of these birds in a photo at all feeding stations. Golden Eagle (Aquila chrysaetos) was not registered on the feeding sites during observation period, although this bird is a breeding species on the territory of the Ustyurt State Nature Reserve. Obviously, this species with a wide food spectrum finds enough live prey in the warm season and does not need to feed on offal. However, a Golden Eagle was captured on November 15 and 16, 2018 on the camera trap set up on Ustyurt sheep remains outside of the feeding station (fig. 5: 2). Probably, as in the case with Cinereous Vulture, only relatively whole and fresh carcasses of ungulates attract Golden Eagle. 
шие птицы. Все гнёзда грисров расположены однотипно - на плоских вершинах скал-останцов либо на скальных выступах у основания чинка, и, как правило, хорошо заметны с большого расстояния. Подобное расположение гнёзд характерно мля безлесных ксеросииьных территорий Казахстана, в том числе Устюрта ( $\triangle$ ементьев, 1951; Гаврин и Ар., 1962). Ешё одно обитаемое гнезАо чёрного грисра было впервые выявлено нами в апреле 2018 г. в открытой нише, расположенной в верхней части чинка (обрыва) на высоте около 50 м от основания обрыва и примерно в 5 м от его верхнего края. Таким образом, впервые мия территории УГПЗ подтверждено гнездование четырёх пар чёрного грисра (в предылушие годы удавалось выявить Аишь 2-3 жилых гнезАа) (рис. 2: 2, 3).
Among mammals recorded at the feeding sites were: Wolf (Canis lupus) (1-2 individuals in a photo) (fig. 5: 3), Red Fox (Vulpes vulpes karagan) (1-2 in a photo), Caracal (Caracal caracal) (1 in a photo) (fig. 5: 4), Wild Cat (Felis silvestris lybica) (1 in a photo), Brandt's Hedgehog (Paraechinus hypomelas) (1-2 in a photo), Long-Eared Hedgehog (Hemiechinus auritus) (1 in a photo), Tolai Hare (Lepus tolai) (1 in a photo), Yellow Ground Squirrel (Spermophilus fulvus) (1 in a photo), Goitered Gazelle (Gazella subgutturosa) (1-2 in a photo) and Ustyurt Sheep (Ovis vignei arkal) (1-4 in a photo).

In 2018, Steppe Polecat (Mustela eversmanni) (1 in a photo) was registered on one of the feeding sites; this species was known previously from only one reliable finding on the territory of the Reserve. It is obvious
Рис. 2. Белоголовые сипы (Gyps fulvus) в урочище Табаната в северной части УГПЗ, 28.04.2018 г. - 1, нетипичное расположение гнезда чёрного грифа (Aegypius monachus) в нише в верхней части обрыва в урочище Кугусем, 08.04.2018 - 2, 3. Фото Е. Полонского и М. Пестова.

Fig. 2. Griffon Vultures (Gyps fulvus) at Tabanata area in the northern part of the Ustyurt Reserve, 28/04/2018 - 1 Atypical location of Cinereous Vulture (Aegypius monachus) nest in a niche on the top of the cliff in Kokusem area, 08/04/2018 - 2, 3. Photos by E. Polonsky and M. Pestov.

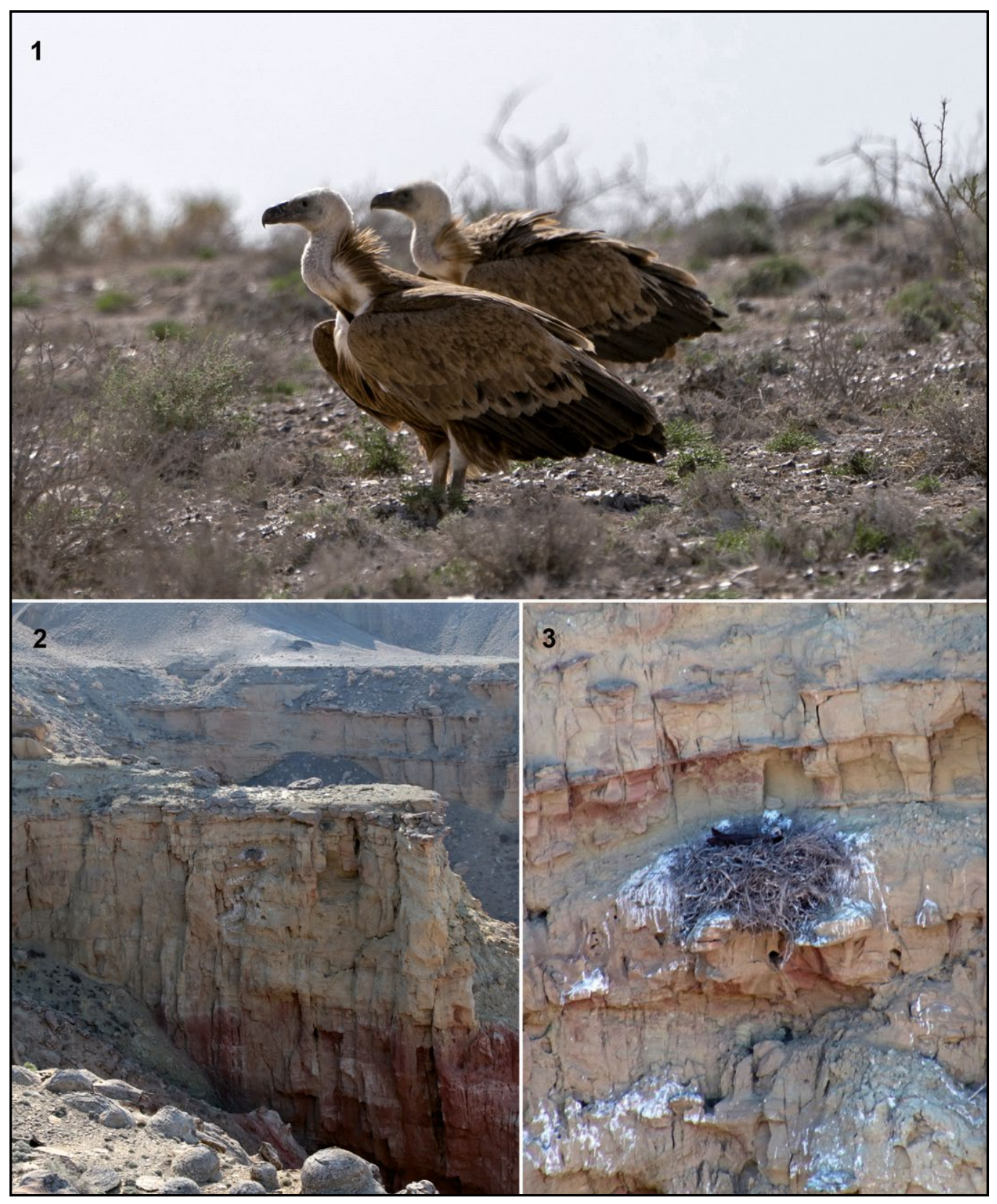


Табл. 1. Посешаемость прикормочных плошацок (привац) хишными птицами-пацамьшиками на территории Устюртского ГПЗ в 2016 и 2018 гг.

Table 1. Attendance of vulture species at the feeding stations on the territory of the Ustyurt State Nature Reserve in 2016 and 2018.

\begin{tabular}{|c|c|c|c|c|c|c|}
\hline \multirow{2}{*}{$\begin{array}{l}\text { Виды птиц, отмеченные на } \\
\text { привацах } \\
\text { Species of vultures observed at } \\
\text { the feeding stations }\end{array}$} & \multicolumn{2}{|c|}{$\begin{array}{r}\text { Пиошамка } 1 \\
\text { Aтжол } \\
\text { Feeding station } 1 \\
\text { Atzhol } \\
\end{array}$} & \multicolumn{2}{|c|}{$\begin{array}{r}\text { Плошамка } 2 \\
\text { Шаровые конкреции } \\
\text { Feeding station } 2 \\
\text { Ball concretions } \\
\end{array}$} & \multicolumn{2}{|c|}{$\begin{array}{r}\text { Плошамка } 3 \\
\text { Жаман Кенцерли } \\
\text { Feeding station } 3 \\
\text { Zhaman Kenderly } \\
\end{array}$} \\
\hline & $\begin{array}{r}\text { Koл-во суток }^{*} \\
\text { Number of } \\
\text { days }^{*}\end{array}$ & $\begin{array}{r}\text { Kon-Bo эк3. * } \\
\text { Number of } \\
\text { Ind. }{ }^{* *}\end{array}$ & $\begin{array}{r}\text { Kon-во суток } \\
\text { Number of } \\
\text { days }\end{array}$ & $\begin{array}{r}\text { Koл-во экз. } \\
\text { Number of } \\
\text { Ind. }\end{array}$ & $\begin{array}{r}\text { Kon-во суток } \\
\text { Number of } \\
\text { days }\end{array}$ & $\begin{array}{r}\text { Kол-во экз. } \\
\text { Number of } \\
\text { Ind. }\end{array}$ \\
\hline & $2016 / 2018$ & $2016 / 2018$ & $2016 / 2018$ & $2016 / 2018$ & $2016 / 2018$ & $2016 / 2018$ \\
\hline $\begin{array}{l}\text { Обыкновенный стервятник } \\
\text { Neophron percnopterus }\end{array}$ & $56 / 13$ & $2 / 2$ & $16 / 31$ & $2 / 1$ & $5 / 14$ & $1 / 3$ \\
\hline $\begin{array}{l}\text { Чёрный гриф } \\
\text { Aegypius monachus }\end{array}$ & $2 /-$ & $1 /-$ & $-1-$ & $-/-$ & $-/ 1$ & $-/ 3$ \\
\hline $\begin{array}{l}\text { Белоголовый сип } \\
\text { Gyps fulvus }\end{array}$ & $4 /-$ & $1 /-$ & $-/ 1$ & $-/ 1$ & $-1-$ & $-/-$ \\
\hline
\end{tabular}

Примечания / Notes:

* - Кол-во суток - количество суток, в течение которых данный вид отмечен на прикормочной плошацке за весь период наблюдения. / Total number of days for each species present at the feeding station for the entire period of observation.

** - Кол-во экз. - максимальное количество особей данного вила, одновременно попавших в калр фотоловушки. / Махіmum number of individuals of each species simultaneously captured in a photo of the camera trap.

В отличие от чёрного грисра, обыкновенный стервятник, как правило, гнездится в нишах в верхней части отвесных обрывов. Соответственно, поиск мест гнезАования стервятников представляет собой более сложную задачу и идентисицировать предполагаемое место расположения гнезда удаётся лишь по регулярному присутствию в нише взрослых птиц и белым потёкам помёта, которые, впрочем, плохо заметны на известняковых обрывах чинков Устюрта, что Аополнительно усложняет поиск мест гнездования. В 2018 г., как и в 2016 г., нам удамось обнаружить мишь Ава места вероятного гнездования стервятника на участке чинка от кордона Мамекказган $\Delta о$ урочиша Кокесем в северной части заповедника. В каждом из них были отмечены по Аве взрослые птицы. Вероятно, обшее количество стервятников, гнездяшихся на территории УГПЗ, не превышает 3-4 пар.

28 апреля 2018 г. российские фотограсы Е.В. Полонский, И.А. Чернышёв, а также сопровожлавший их научный сотрудник УГПЗ Б.А. Сайынов, в районе урочиша Табаната в северной части заповедника наблюдали группу из 7 белоголовых сипов, при этом вблизи не было обнаружено никаких останков крупного павшего животного (устное сообшение). Три из 7 сипов были ссотограсрированы Евгением Полонским (рис. 2: 1).

За время использования прикормочных плошацок с фотоловушек получено несколько тысяч фотограсий, большинство that most mammals were attracted by the smell of offal or were at the feeding stations by accident. Feeding on offal was observed only for the wolf and foxes.

Data on the Caracal obtained in 2018 are of considerable interest, as this animal was earlier recorded on the territory of the Ustyurt State Nature Reserve only on a few occasions. In 2016, Caracal was captured only once on one of the feeding stations at nighttime, while in 2018, Caracal was registered on all three feeding stations both at night and daytime over the course of 14 days, with at least two different adults. Most likely, these observations indirectly indicate a possible increase in the number of this species due to favorable weather conditions in the spring-summer period of 2016 and 2017, when relatively heavy rainfall caused a good food supply for herbivorous animals, including rodents and hares, which are primary prey for Caracal.

However, the most unexpected and significant result of our project was the capturing of the Persian Leopard (Panthera pardus saxicolor) with camera traps on the territory of the Ustyurt State Nature Reserve. The Persian Leopard was assessed as Endangered on the IUCN Red List in 2008 (Khorozyan, 2008).

According to experts, until the end of the $20^{\text {th }}$ century, the leopard had never been observed in Kazakhstan (Heptner, Sludsky, 1972; Sludsky et al., 1982). Only in the last two decades, three reliable incidents of illegal killing of this species became known: the first incident occurred in 2000 in Zhambyl 
Рис. 3. Взросиый стервятник (Neophron percnopterus) на приваце $N^{\circ}$ 2, 11.07.2018 г.

- 1 , молодой стервятник в возрасте 2-3 лет на приваце № 1 21.05.2018 г. - 2, стервятники - Ава взросиыХ и молодой - на приваце № 3, 22.11.2018 г. - 3, белоголовый сип и ворон (Corvus corax) на приваце № 2 , 07.06.2018 г. - 4 , пара чёрных грисров на приваце $N^{\circ} 3$,

22.11.2018 г. -5 , конфликт из-за Аобычи пары чёрных грисов на приваце $N^{\circ} 3$, 22.11.2018 г. -6 Фото с фотоловушек, установленных авторами.

Fig. 3. Adult Egyptian Vulture (Neophron percnopterus) on the feeding-station $N^{\circ} 2$, 11/07/2018 - 1, a young vulture at the age of 2-3 years on the feeding-station $N$ № 1 , 21/05/2018 - 2, the Egyptian Vultures - a pair of adults and the juvenile - on the feeding-station $N$ № 3 , 22/11/2018 - 3, Griffon Vulture and the Raven (Corvus corax) on the feeding station $N^{\circ} 2$ 07/06/2018 - 4, pair of the Cinereous Vulture on the feeding station № 3, 22/11/2018 - 5 , the conflict over prey between two Cinereous Vultures on the feeding station $N^{\circ} 3$, 22/11/2018 - 6. Photos from the camera traps set up by the authors. из которых оказаиись информативны - на них присутствуют изображения птиц и млекопитающих. Среди прочих, были получены многочисленные фото стервятников, а также чёрных грисоов и белоголового сипа. $\triangle$ анные о присутствии различных виАов птиц-пахальшиков на привалах в 2016 и 2018 гг. представлены в таблице 1 .

Таким образом, в 2018 г., так же, как и в 2016, на прикормочных площахках с помошью фотоловушек отмечено присутствие трёх видов птиц-пацальшиков.

\section{Обыкновенный стервятник (Neophron percnopterus)}

Как и в 2016 г., чаше всего привады посешаиись обыкновенными стервятниками (рис. 3: 1, 2, 3). Ранее мы ориентировочно оценивали численность данного вида на территории УГПЗ в 3-5 гнезАяшихся пар (Пестов и Ар., 2017). Соответственно, в 2018 г. стервятники вновь отмечены на всех трёх прикормочных плошадках. Максимамьная посешаемость отмечена на приваце № 2 - одиночные стервятни- region (Shakula, 2004); and two more leopards were killed in Mangystau region in 2007 and 2015 (Plakhov et al., 2016).

In the evening of September 29, 2018, the presence of Persian Leopard in the Ustyurt State Nature Reserve was registered for the first time. On November 6, 2018, the leopard was camera-trapped again at the same feeding station in the nighttime (fig. 5: 5). For the third time, Persian Leopard was recorded on December 7, 2018, in the daytime at another feeding station (Pestov et al., 2019) (fig. 5: 6).

When the leopard visited the feeding sites, there were camel bone remains only, with no nutritional value, but still acting as a long-term odor bait. Most likely, it was the same leopard-adult male, and on the second and third occasions, this is clearly confirmed by matching patterns in the leopard's coat. Three camera trap records over a period of 70 days in the Ustyurt State Nature Reserve allow us to hope that the leopard will remain in the area. Habitat conditions are close to optimal: this area has little

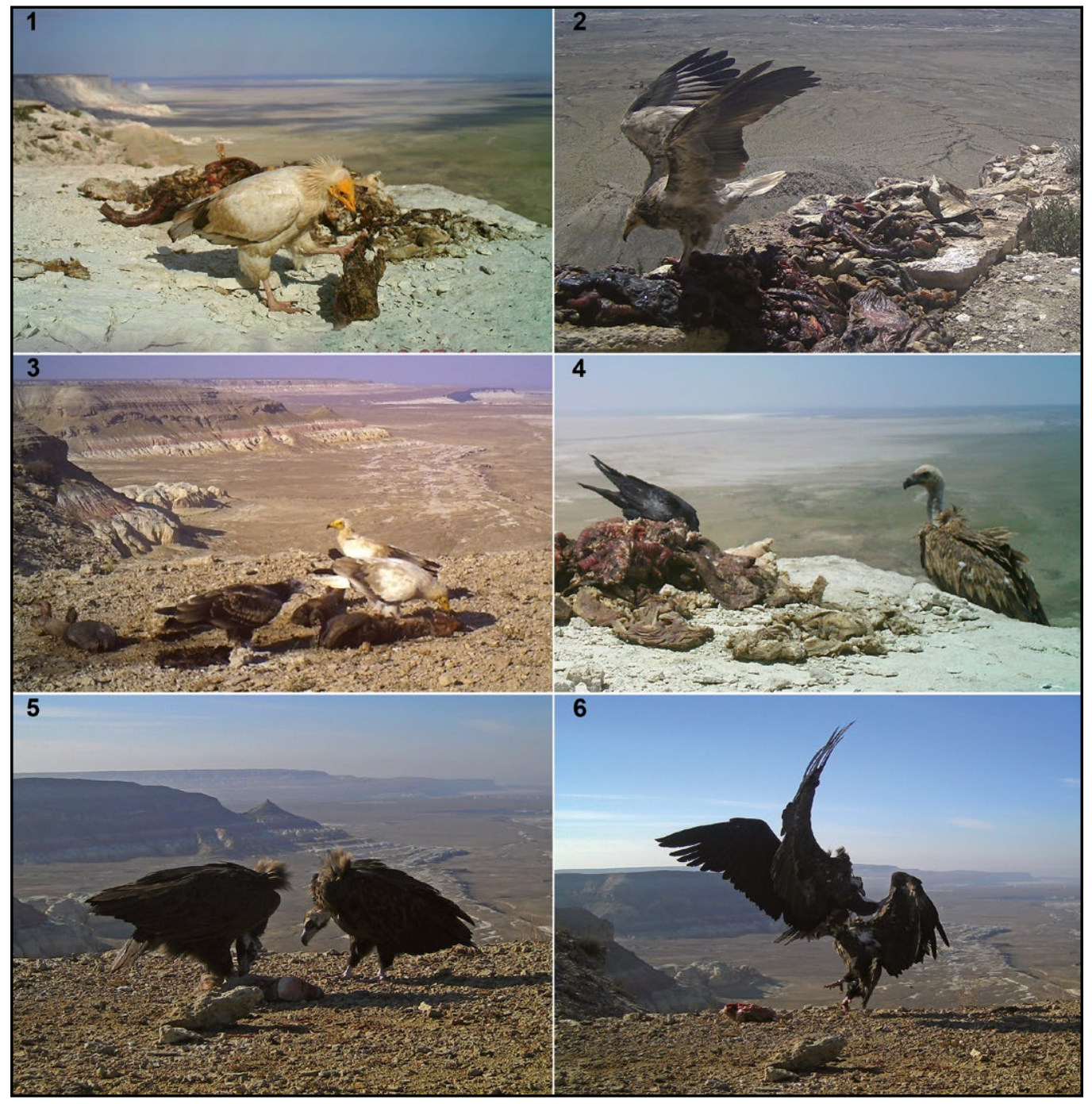


ки появлялись здесь в течение 31 суток из 133 (временной интерваи между появлением первого и последнего стервятника на привацах), что составило $27 \%$ от обшей продолжительности наблюдений. Максиманьное количество птиц в камре - 3 (Аве взрослых и 1 сеголеток), отмечено на плошахке № 3. Пребывание стервятников на плошалках отмечено искиючительно в светлое время суток во временном интервале от 5 ч 41 мин Ао 20 ч 42 мин.

Максимальная продолжительность пребывания стервятников на приваце в течение одних суток составила около 2 часов 40 минут: 01.09.2018 г. Аве взрослые птицы и сеголеток суммарно находились на приваце с 8 ч 57 мин Ао 11 ч 36 мин по местному времени, с Авумя перерывами по 10-15 минут. ОАнако, в большинстве случаев продолжительность пребывания взрослых стервятников на приваде не превышаяа 10-20 мин за одно посешение. Первое появление стервятника на плошалке отмечено 25.04.2018 г., последнее - 06.09.2016 г. Необходимо отметить, что стервятники - перелётные птицы и осенью покиАают места своего гнездования $(\Delta \mathrm{e}$ ментьев, 1951; Гаврин и мр., 1962).

Общая (суммарная мия всех трёх привах) посешаемость стервятниками прикормочных плошалок в 2018 г. - 58 фотоловушко-суток за весь период присутствия стервятников на привацах (44\%) - оказалась несколько ниже, чем в 2016 г., когАа этот показатель составил 77 фотоловушко-суток (53\%). Возможно, это связано с некоторым улучшением в состоянии кормовой базы Аанного вида, который не является облигатным некросрагом ( $\triangle$ ементьев, 1951; Гаврин и Ар., 1962).

Наши попытки оценки обшего количества стервятников, посешаюших прикормочные плошахки, путём сравнения дат и времени их пребывания на различных плошалках, как и в 2016 г., не увенчаиись успехом: одновременное пребывание стервятников на разных привацах отмечено не было. Более успешной оказалась попытка идентисрикации и подсчёта отдельных особей стервятника по особенностям их окраски, которая, как известно, меняется с возрастом (Аементьев, 1951 ; Гаврин и мр., 1962). Так, 1 и 3 сентября 2018 г. на плошахке № 3 вместе с Авумя взрослыми птицами (вероятно - родителями) нами впервые был отмечен сеголеток стервятника с характерным тёмно-бурым опере- human disturbance, its relief provides good cover and within a radius of several kilometers, there are springs with reed beds.

Leopards are likely to periodically migrate from neighboring Turkmenistan (Geptner, Sludsky, 1972; Lukarevsky, 2001; Red Data Book of Turkmenistan, 2011). In 1989, some leopard tracks were spotted in the Kulansai gorge at the Kara-Bogaz-Gol bay in northwestern Turkmenistan (Lukarevsky, 2001). This site in Turkmenistan is the closest to the place of leopard observation in the Ustyurt State Nature Reserve (around $170 \mathrm{~km}$ ).

Based on the data of typical individual territory sizes that leopards occupy in Turkmenistan (see Lukarevsky, 2001), 1-2 adult males and several females can live in the Ustyurt Reserve in the future.

The appearance of the leopard in Mangystau provides additional arguments in favor of adopting measures to preserve all the biological and landscape diversity of the Ustyurt Plateau. It is evident that sustainable conservation of all components of the ecosystem would allow protecting of rare native species, including vultures and the leopard. We propose to increase the buffer zone of the Reserve up to $10 \mathrm{~km}$ and to establish a new protected area in the South Ustyurt, including the Kaplankyr "Chink", near the border of Kazakhstan with Turkmenistan and Uzbekistan. Relevant proposals were submitted to the Committee of Forestry and Fauna of the Ministry of Agriculture of the Republic of Kazakhstan.

The leopard currently is not listed in the Red Data Book of the Republic of Kazakhstan (2010). With the support of the Central Asian Desert Initiative (CADI) project ${ }^{46}$, we have already developed a biological justification for including the Persian Leopard in the Red Data Book of the Republic of Kazakhstan. At present, an Action Plan on Persian Leopard in Kazakhstan is being prepared. Both documents will be submitted to the Government of Kazakhstan in the near future.

The project on monitoring of vulture supplemental feeding stations and assessment of vulture population status in Mangistau Region was successfully completed in 2018 and the previously set objectives have generally been fulfilled. In the future, the range of activities of our project will be expanded, we are planning to continue the monitoring of rare birds of prey and mammals listed in the Red Data Book of the Republic of Kazakhstan and IUCN. 
нием с рыжеватыми пестринами и голубоватой окраской восковицы и кожи кица. Ешё один молодой стервятник в возрасте 2-3 лет с серовато-бурым оперением был отмечен на приваце № 1 21.05.2018 г. Идентисрицировать индивидуамьно взросмых стервятников, а значит и более точно оценить количество птиц, посетивших привады, нам не удалось. Таким образом, на привацах в 2018 г. были отмечены 2 неполовозрелых и не менее 2 взрослых стервятников.

На фотограсиях с фотоловушек имеются многочисленные подтверждения активного питания стервятников на привахах, а также ситуации, когАа улетаюший стервятник уносит часть пиши в киюве. Стервятники неоднократно отмечамись на приваце одновременно с несколькими воронами (Corvus corax) и, как правило, спокойно на них реагировами.

\section{Чёрный грифр \\ (Aegypius monachus)}

В 2016 г. оАин чёрный гриср был отмечен лишь на плошалке № 1, дважды в светлое время суток: 25.05.2016 г. в течение 10 минут и 30.08.2016 г. в течение 40 минут, в том числе вместе с воронами, стервятником и сипом. Получено около 70 фото грисра на приваце, однако непосредственно поедание им субпродуктов не было отмечено. Столь низкая посешаемость привац грисром (2 суток из 210 около $1 \%$ от общей продолжительности наблюдений) стала мяя нас неожиданностью, учитывая наличие нескольких гнезАяшихся пар данного вида на территории УГПЗ, в том числе - вблизи обустроенных нами привах (Пестов и Ар., 2017). Было слелано предположение, что низкая посешаемость привац связана с Аостаточно узкой пишевой специализацией: в отличие от стервятника и сипа, гриср предпочитает

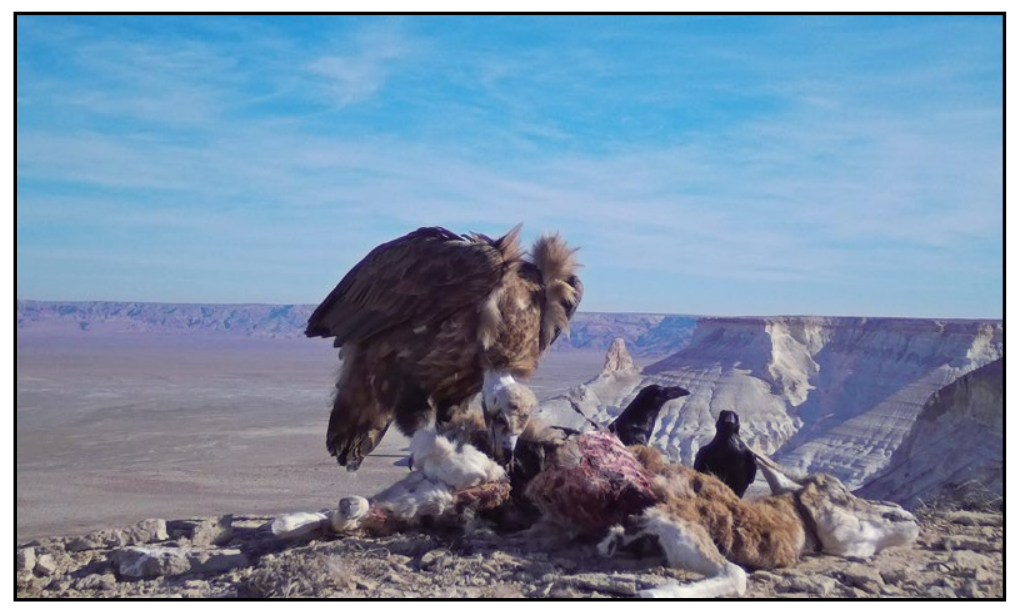

мясо и шкуру павших животных (Аементьев, 1951), которые отсутствоваяи на наших привахах.

В 2018 г. с апреля по октябрь ни на одной из привац чёрный гриср не был отмечен, хотя нами на территории УГПЗ были $А$ стоверно установлены 4 гнездяшиеся пары. Последняя порция прикормки на плошалке № 3 была выложена 15.11.2018 г., причём на этот раз, вместе с обычными субпроАуктами, был выложен коровий эмбрион с Алиной тела около 80 см. Именно на этой площацке 21.11.2018 г. в 12:48 появился первый гриср, спустя 4 минуты к нему присоединился второй. Обе птицы с небольшими перерывами присутствовами на приваце мо 14:04, активно кормились на останках эмбриона и иногАа консликтоваяи из-за добычи (рис. 3: 5, 6). Аважды к ним подметал третий грифр, однако сидяшим на приваце он так и не был отмечен. Обшая посешаемость привах составила менее 0,5\% (1 сутки из 220 за весь периоА наблюдений). Ешё один чёрный гриср бы отмечен 16 ноября в течение 25 минут (рис. 4) вне стационарной привады на фотоловушке, установленной на останках уриала (Ovis vignei arkal).

Таким образом, наше предположение о низкой привлекательности подкормки, состояшей из субпродуктов, мяя чёрного грисра полностью подтвердилось. Очевилно, что его привлекают лишь целые трупы животных. Возможно, что повысить привлекательность подкормки мия грисов и посешаемость ими привах можно, помешая субпродукты внутри шкур животных (баранов и $\Delta$ р.).

\section{Белоголовый сип (Gyps fulvus)}

Белоголовый сип в 2016 г. был отмечен мишь на приваце № 1 в светлое время в течение 4 суток (около 2\% от обшей проАолжительности наблюдений), в том числе 30.08.2016 г. в течение 6 минут - совместно со стервятником, грисом и несколькими воронами. На фото с фотоловушек

Рис. 4. Чёрный гриср и вороны на останках уриana (Ovis vignei arkal) вне стационарной привацы. 16.11.2018 г. Фото с фотоловушки, установиенной авторами.

Fig. 4. Cinereous Vulture and Ravens on the remains of the Ustyurt sheep (Ovis vignei arkal) outside the stationary feeding station. 16/11/2018. Photo from the camera trap set up by the authors. 
было отмечено поедание субпродуктов (Пестов и др., 2017). В 2018 г. еАинственный раз один сип был отмечен 7 июня с 12:17 по 12:23 по местному времени на приваце № 2 (рис. 3: 4). Поедание прикормки не отмечено. Крайне низкая посешаемость сипом привац (менее 0,5\%) в целом соответствует его статусу редкого, залётного, не гнездяшегося на данной территории вида.

\section{Аругие виды птиц и млекопитающих}

Помимо стервятников, грисоов и сипов, на привадах отмечены ешё 2 вида птиц, привлечённых подкормкой: степной орёл (рис. 5: 1) - 1 экз. в кахре на приваце № 1 и ворон (Corvus corax) - $\Delta$ о 7 экз. в кадре на всех привалах. Как и в 2016 г., на привадах с субпродуктами не был отмечен беркут (Aquila chrysaetos), который Аовольно часто встречается и достоверно гнездится на территории заповедника. Очевидно, этот универсаиьный пернатый хишник с широким пишевым спектром находит зАесь в тёплое время года $\Delta$ остаточно живой Аобычи в виде среднеазиатских черепах (Agrionemys [Testudo] horsfieldii), азиатских кекликов (Alectoris chukar), зайцев (Lepus tolai), жёлтых сусмиков (Spermophilus fulvus), молодняка Ажейранов (Gazella subgutturosa), уриалов и Ар., и не нуждается в использовании пахали. ОАнако, беркут был зарегистрирован 15 и 16 ноября 2018 г. вне стационарной привады на фотоловушке, установленной на останках уриала (рис. 5: 2). Вероятно, как и в случае с чёрным грисом, беркута привлекают мишь относительно целые и свежие трупы копытных животных.

Также на привацах был отмечен ряд виАов птиц, чьё присутствие здесь не связано с потреблением ими прикормки: обыкновенная пустельга (Falco tinnunculus), фимин (Bubo bubo), азиатские кеклики, каменки двух видов (Oenanthe pleschanka и Oenanthe deserti), серая мухоловка (Muscicapa striata), умод (Upupa epops) и белобрюхий стриж (Tachymarptis melba). Очевидно, что фрилин был привлечён на привады посешаюшими их ежами; воробьиные птицы и уАОА были привлечены обилием мух на субпродуктах, выкиадываемых в качестве прикормки; кекиики, пустельга и стриж попаии в камр случайно, перемешаясь вблизи привац.

Из млекопитаюших на привацах, как и в 2016 г., были отмечены: волк (Canis lupus) - 1-2 экз. в кахре (рис. 5: 3), миси- ца-караганка (Vulpes vulpes karagan) - 1-2 экз. в камре, каракаи (Caracal caracal) - 1 экз. в канре (рис. 5: 4), степной кот (Felis silvestris lybica) - 1экз. в камре, миинноиглый ёж (Paraechinus hypomelas) - 1-2 экз. в камре, ушастый ёж (Hemiechinus auritus) - 1 экз. в камре, заяц-толай - 1экз. в камре, жёлтый суслик - 1 экз. в камре, джейран 1-2 экз. в камре и устюртский горный баран (уриац) (Ovis vignei arkal) - 1-4 экз. в кахре. В 2018 г. на одной из привац впервые был отмечен степной хорь (Mustela eversmanii) - 1 экз. в камре, ранее известный по единственной Аостоверной находке м^я территории УГПЗ. Очевидно, что большинство млекопитаюших были привлечены на привады запахом, мибо оказались там случайно. Непосредственно потребление подкормки отмечено только Аля волка и лисицы.

Значительный интерес представляют данные о каракаме, ранее известном мия территории УГПЗ кишь по еАиничным встречам. Если в 2016 г. каракал был отмечен лишь однажАы на одной из привац, то в 2018 г. каракам был зарегистрирован на всех трёх привалах, суммарно встречаемость составила 14 суток, при

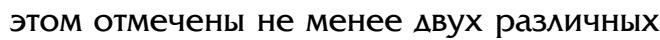
взрослых особей. Вероятной причиной увеличения встречаемости каракала на фотоловушках, косвенно свидетельствуюшего о возможном росте численности Аанного вида, могут быть благоприятные погодные условия весенне-летнего периода 2016 и 2017 гг., когАа относительно обильные осаАки обусловили хорошую кормовую базу мия растительноянных животных, в том числе грызунов и зайцев, являюшихся основными пишевыми объектами мля каракама.

Однако, пожалуй самым неожиданным и значимым результатом нашего проекта стала регистрация переднеазиатского меопарла (Panthera pardus saxicolor) на территории УГПЗ. Переднеазиатский леопард - редчайший представитель семейства кошачьих, занесённый в Красный список МежАународного союза охраны природы (IUCN) в категории "находяшийся в опасности" или "исчезаюший" - Endangered (Khorozyan, 2008). Ареа^ Аанного подвида леопарда сильно фрагментирован и охватывает Иран, Асганистан, Туркменистан, Азербайджан, Нагорный Карабах, Абхазию, Армению, Грузию, Турцию, Пакистан и Северный Кавказ на территории России (Jacobson et al., 2016). 
Рис. 5. Степной орёА (Aquila nipalensis) и ворон на приваце $N^{\circ} 1$, 07.09.2018 г. - 1, беркут (Aquila chrysaetos) и ворон на останках уриала вне стационарной привады, 16.11.2018 г. - 2, волк (Canis lupus) на приваце $N^{\circ}$ 3, 25.11.2018 г. - 3, каракаи (Caracal caracal) на приваце № 2, 22.11.2018 г - 4 переднеазиатский меопард (Panthera pardus saxicolor) на одной из привац на территории Устюртского ГПЗ, 06.11 .2018 г. - 5 и 07.12.2018 г. - 6. Фото с фотоловушек, установленных авторами.

Fig. 5. Steppe Eagle (Aquila nipalensis) and the Raven on the feeding station $N^{\circ}$ 1, 07/09/2018 - 1 Golden Eagle (Aquila chrysaetos) and the Raven on the remains of the Ustyurt sheep outside the stationary feeding station, 16/11/2018 -2 , Wolf (Canis lupus) on the feeding station № 3, 25/11/2018 - 3, Caracal (Caracal caracal) on the feeding station № 2, 22/11/2018-4 Persian leopard (Panthera pardus saxicolor) on one of the feeding stations at the territory of the Ustyurt State Nature Reserve, $06 / 11 / 2018$ - 5 and 07/12/2018 - 6. Photos from the camera traps set up by the authors.
Вплоть до конца XX века леопард никогла ранее не отмечался специалистами м^я территории Казахстана (Гептнер, Слуаский, 1972; Слудский и нр., 1982). И мишь в последние Аесятилетия стали известны 3 Аостоверных фракта незаконной Аобычи этого зверя: первый - в 2000 г., на территории Жамбылской области, ешё 2 леопарда были убиты в Мангистауской области в 2007 и 2015 г. (Плахов и мр., 2016).

Впервые мия территории Казахстана фото живого переднеазиатского леопарда было получено с помошью фотоловушки на одной из наших привац 29.09.2018 г. в тёмное время суток, с 22:57 $А$ о 22:59 по местному времени. На той же приваце леопард вновь был отмечен 06.11.2018 г. в тёмное время суток (в 06:57) в течение одной минуты (рис. 5: 5). Третий случай ре-

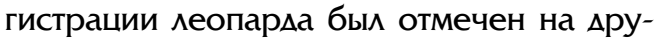
гой прикормочной пмошаяке 07.12.2018 г. в светлое время суток в течение 5 минут (с 16:27 по 16:31). Расстояние между данными привадами составляет около 19 км (рис. 5: 6) (Пестов и Ар., 2019).
К моменту посешения леопардом привах на них оставаяись мишь "старые" костные останки верблюда, не представляюшие пишевой ценности, но выполняюшие роль Аолговременной запаховой приманки. На фото видно, как леопард подходит К ним, обнюхивает и уходит. Вероятно, это был один и тот же зверь - взрослый самец, причём во втором и третьем случаях это однозначно подтверждается совпацением характерного расположения пятен в окраске леопарда (в первом случае качество фотограсий было недостаточно $А л я$ сравнения).

Трёхкратная регистрация леопарда с интервалом в 70 суток на участке Запацного чинка плато Устюрт протяжённостью около 19 км на территории Устюртского ГПЗ позволяет намеяться, что этот зверь останется жить на Аанной территории. Условия обитания здесь близки к оптимальным: Аанная местность редко посешается человеком, её рельеср отличается обилием потенциальных убежиш, в рахиусе нескольких километров зАесь имеются родники с зарослями тростника, вбли-

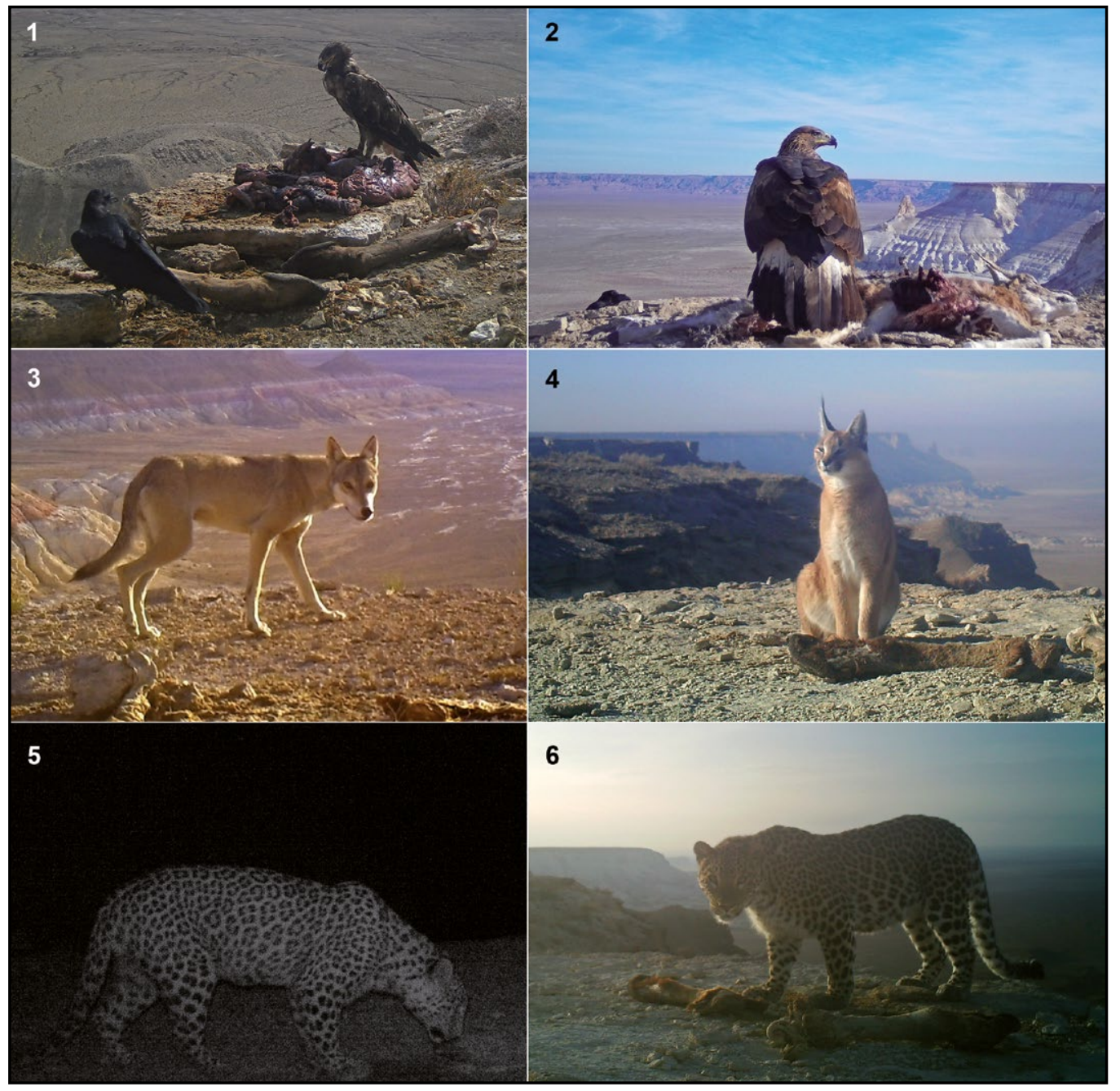


зи которых в ноябре 2018 г. нами было отмечено около 100 уриалов. В целом, по Аанным учётов численности копытных, проведённых сотрудниками Устюртского заповедника с 30 октября по 2 ноября 2018 г., на его территории были отмечены 548 уриалов и 360 Ажейранов. Из Аругих потенциальных пишевых объектов леопарда здесь также Аостаточно обычны заяц-толай, жёлтый суслик и кеклик (Пестов и Ар., 2019).

Очевидно, что в Мангистау меопарды периодически попадают из сопредельного Туркменистана (Гептнер, Слудский, 1972; Аукаревский, 2001; Красная Книга Туркменистана, 2011). В северо-запацном Туркменистане самая северная точка его встречи была отмечена в 1989 г. в урочише Кулансай на чинке замива Кара-БогазГол (Аукаревский, 2001). Это примерно в 170 км к югу от места встречи леопарда в УГПЗ. Судя по Аанным о размерах инАивидуамьных участков меопарда в Туркменистане (см. Аукаревский, 2001), на территории Устюртского заповедника в перспективе могут обитать 1-2 взрослых самца и несколько самок.

Появление леопарда в Мангистау даёт Аополнительные аргументы в пользу необходимости оптимизации комплекса мер по сохранению всего биологического и мандшастного разнообразия Устюрта. Очевидно, что только репрезентативное сохранение всех компонентов экосистемы позволит сохранить обитаюшие здесь редкие виды, и в том числе - птицпахальщиков и леопарда. В частности, мы считаем необходимым расширение охранной зоны Устюртского ГПЗ Ао 10 км и создание новой особо охраняемой природной территории на Южном Устюрте, вкиючая чинк Капланкыр, вблизи государственной границы Казахстана с Туркменистаном и Узбекистаном. Соответствуюшие предиожения уже переданы нами в Комитет лесного хозяйства и животного мира MCX PK.

Необходимо также отметить, что леопард не внесён в Красную книгу Республики Казахстан (2010). В настояшее время нами, при поммержке проекта Central Asian Desert Initiative (CADI) ${ }^{\mathbf{4 6}}$, уже разработано биологическое обоснование мля внесения переднеазиатского леопарда в Красную книгу Республики Казахстан и ведётся подготовка Плана действий по ^еопарду в Казахстане. Оба документа будут переданы в Правительство Казахстана дмя утверждения и реаиизации.

Таким образом, проект по подкормке пацаиьшиков в Устюртском заповеднике в 2018 г. успешно завершён, поставленные заяачи, в основном, выполнены. Считаем целесообразным продолжение мониторинга состояния падальшиков на казахстанской части плато Устюрт. Вероятно, в Аальнейшем, с учётом полученных результатов, тематика нашего проекта будет расширена $\Delta о$ мониторинга различных видов хишных птиц и млекопитаюших на территории УГПЗ, в том числе с использованием фотоловушек и различных пишевых и запаховых приманок.

\section{Блатодарности}

Мы благодарим сотрудников Устюртского заповедника Жаигаса Усталова, Сапаргами Нурмагамбетова, Аостык Нурмухамбетову, Акнияза Пулатова, Берика Сайынова, Орынбека Муханова, Коныса Жаймуханова, Берика Рзаева, Мурата Оразбаева, Каидыбая Мамаева за помошь в организации и проведении экспедиционных исследований на территории заповедника; фотографа Евгения Полонского (Россия) - за фото белоголовых сипов и информацию об их встрече на территории УГПЗ; $А$ мтрия $\Delta \mathrm{e}-$ нисова (ГПЗ "Керженский», Россия) - за помошь в подготовке картограсического материала с использованием программы QGIS 2.8. Особую благодарность выражаем Фонду Русрфорда (Rufford Foundation) за повторную финансовую подцержку нашего проекта.

\section{Аитература}

Гаврин В.Ф., Аолгушин И.А., Кузьмина М.А., Корелов М.Н. Птицы Казахстана. Т. 2. АлмаАта: Иза-во АН Казахской ССР, 1962. 779 с. [Gavrin V.F., Dolgushin I.A., Kuzmina M.A., Korelov M.N. Birds of Kazakhstan. Vol. 2. AlmaAta, 1962: 1-779. (in Russian).]

Гептнер В.Г., Сиудский А.А. Млекопитаюшие Советского Союза. В трёх томах. Том второй (часть вторая). Хишные (гиены и кошки). М.: "Высшая школа", 1972. С. 169-171. [Geptner V.G., Sludsky A.A. Mammals of the Soviet Union. Vol. 2 (part. 2). Predatory (Hyenas and Cats). Moscow, 1972: 169-171. (in Russian).]

Аементьев Г.П. Отряд хишные птицы: Асcipitres ими Falconiformes. - Птицы Советского Союза. Т. 1. М.: Сов. Наука, 1951. С. 70-341. [Dementiev G.P. Birds of prey: Accipitres or Falconiformes. - Birds of the Soviet Union. Vol. 1. Moscow, 1951: 70-341. (in Russian).] URL:

46 http://cadi.uni-greifswald.de/ru/start-2/ 
http://rrrcn.ru/ru/archives/14389 Аата обрашения: 08.03.2017.

Карякин И.В., Новикова А.М., Паженков А.С. Результаты российской экспедиции на запаце Казахстана в 2003 г. - Казахстанский орнитологический бюмлетень 2003. Алматы, 2004. C. 24-27. [Karyakin I.V., Novikova L.M., Pazhenkov A.S. Results of the Russian expedition in Western Kazakhstan in 2003. - Kazakhstanian Ornithological Newsletter 2003. Almaty, 2004: 24-27. (in Russian).]

Ковшарь А.Ф., Аякин Г.Ю. Гнездовая фауна птиц Устюртского заповедника. - Территориаиьные аспекты охраны птиц в Средней Азии и Казахстане / Под ред. С.А. Букреева. М., 1999. C. 30-33. [Kovshar A.F., Dyakin G.Yu. Breeding fauna of birds of the Ustyurt State Nature Reserve. - Territorial aspects of bird conservation in Central Asia and Kazakhstan / S.A. Bukreev Ed. Moscow, 1999: 30-33. (in Russian).]

Красная книга Республики Казахстан. ИзА. 4-е, переработанное и дополненное. Том I.: Животные; Часть 1: Позвоночные. Амматы, 2010. 324 c. [Red Data Book of the Republic of Kazakhstan. $4^{\text {th }}$ edition. Volume I.: Animals, Part 1: Vertebrates. Almaty, 2010: 1-324. (in Russian).]

Красная книга Туркменистана. Беспозвоночные и позвоночные животные. Т.2 Ашхабал: Ыیым., 2011. 384 с. [Red Data Book of Turkmenistan. Invertebrates and vertebrates. Vol. 2. Ashgabat, 2011: 1-384. (in Russian).]

Костин С.Ю., Багрикова Н.А. Опыт оценки численности крымской популяции птиц некрофагов. - Устойчивое развитие особо охраняемых природных территорий. Том 3: Сборник статей III Всероссийской научно-практической консеренции (30 ноября - 2 мекабря 2016 г., Сочи). Сочи: ГБУ КК «Природный орнитологический парк в Имеретинской низменности", $\Delta$ ониздат, 2016. С. 131-139. [Kostin S.Yu., Bagrikova N.A. Experience in estimating the number of Crimean bird population of necrophages. - Sustainable development of protected areas. Volume 3: Collection of articles of the III All-Russian Scientific and Practical Conference (November 30 - December 2, 2016, Sochi). Sochi, 2016: 131-139. (in Russian).]

Левин А.С., Карякин И.В. Результаты экспедиции на Мангышлак и Устюрт в 2004 г. Казахстанский орнитологический бюметень 2004. Алматы, 2005. С. 14-19. [Levin A.S., Karyakin I.V. The results of the expedition to Mangyshlak and Ustyurt in 2004. - Kazakhstanian Ornithological Newsletter 2004. Almaty, 2005: 14-19. (in Russian).]

Левин А.С., Куркин Г.А. Масштабы гибели орлов на миниях электропередачи в Западном Казахстане. - Пернатые хишники и их охрана. 2013. № 27. C. 240-244. [Levin A.S., Kurkin G.A. The Scope of Death of Eagles on Power Lines in Western Kazakhstan. - Raptors Conservation. 27: 240-244.] URL: http://rrrcn.ru/ru/ archives/21230 Аата обрашения: 20.03.2017.
Аукаревский В.С. ЛеопарА, полосатая гиена и волк в Туркменистане. М., Сигнар, 2001. 128 c. [Lukarevsky V.S. Leopard, Hyena and Wolf in Turkmenistan. Moscow, 2001: 1-128. (in Russian).]

Нурмухамбетов Ж.Э., Бойко Г.В. К орнитофауне Устюртского государственного природного заповедника. - Научные труды Устюртского государственного природного заповедника, Жанаозен - Астана, 2009. С. 168-178. [Nurmukhambetov Zh.E., Boyko G.V. To the avifauna of the Ustyurt State Nature Reserve. Scientific Materials of the Ustyurt State Nature Reserve, Zhanaozen - Astana, 2009: 168-178. (in Russian).]

Пестов М.В., Нурмухамбетов Ж.Э. Пахальшики Устюртского государственного природного заповедника, Казахстан. - Пернатые хишники и их охрана. 2012. № 24. С. 205-207. [Pestov M.V., Nurmuhambetov Zh.E. Vultures in the Usturtskiy State Nature Reserve, Kazakhstan. - Raptors Conservation. 2012. 24: 205-207.] URL: http://rrrcn.ru/ru/archives/12409 Аата обрашения: 20.03.2017.

Пестов М.В., Сараев Ф.А., Терентьев В.А., Нурмухамбетов Ж.Э. Итоги проекта "Оценка влияния воздушных миний электропередачи средней мошности на орнитосрауну Мангистауской области (Республика Казахстан)". - Пернатые хишники и их охрана. 2015. № 31. C. 64-74. [Pestov M.V., Saraev F.A., Terentiev V.A., Nurmukhambetov Zh.E. The Project Outcome "Assessment of the Impact of Medium Voltage Power Lines on Avifauna in Mangistau Region (Kazakhstan)". - Raptors Conservation. 2015. 31: 64-74.] DOI: 10.19074/1814-8654-2015-31-64-74URL: http://rrrcn.ru/ru/archives/26094 Аата обрашения: 20.03.2017.

Пестов М.В., Нурмухамбетов Ж.Э., Терентьев В.А., Мухашов А.Т., Пулатов А.А., Турмагамбетов С.М. Итоги проекта по подкормке птиц-пацаиьшиков в Устюртском государственном природном заповеднике (Казахстан) в 2016 году. - Пернатые хишники и их охрана. 2017. № 34. С. 12-26. [Pestov M.V., Nurmukhambetov Zh.E., Terentyev V.A., Mukhashov A.T., Pulatov A.A., Turmagambetov S.M. Results of Project on Supplemental Feeding of Vultures in Ustyurt State Nature Reserve (Kazakhstan) in 2016. - Raptors Conservation. 2017. 34: 1226.] DOI: 10.19074/1814-8654-2017-34-12-26 URL: http://rrrcn.ru/ru/archives/28677 Аата обрашения: 20.03.2017.

Пестов М.В., Нурмухамбетов Ж.Э., Мухашов А.Т., Терентьев В.А. Переднеазиатский леопард Panthera pardus saxicolor (Pocock, 1927) и азиатский шакал Canis aureus Linnaeus, 1758 - новые виды м^я территории Устюртского государственного природного заповедника (Республика Казахстан) Selevinia. 2019. Т. 26. (в печати). [Pestov M.V. Nurmukhambetov Zh.E., Mukhashov A.T., Terentyev V.A. The Persian Leopard Panthera 
pardus saxicolor (Pocock, 1927) and the Asian Jackal Canis aureus Linnaeus, 1758 are new species for the territory of the Ustyurt State Nature Reserve (Republic of Kazakhstan). - Selevinia. 2019. 26. (in press).]

Плахов К.Н. Устюртский государственный природный заповедник. - Заповедники Средней Азии и Казахстана. Аиматы, 2006. С. 107118. [Plakhov K.N. Ustyurt State Nature Reserve. - State Nature Reserves of Central Asia and Kazakhstan. Almaty, 2006: 107-118. (in Russian).]

Плахов К.Н. Устюртский заповедник и его роль в охране природных комплексов АрамоКаспийского водораздела. - Научные труды Устюртского государственного природного заповедника, Жанаозен - Астана, 2009. С 193-347. [Plakhov K.N. Ustyurt State Nature Reserve and its role in the protection of natural complexes of the Aral-Caspian watershed. - Scientific Materials of the Ustyurt State Nature Reserve, Zhanaozen - Astana, 2009: 193-347. (in Russian).]

Пиахов К.Н., Пестов М.В., Нурмухамбетов Ж.Э. Встречи переднеазиатского леопарда в Республике Казахстан. - Териофрауна России и сопредельных территорий. Международное совешание (X Съезд Териологического обшества при РАН). М.: Товаришество научных изданий KMK. 2016. C. 325. [Plakhov K.N., Pestov M.V., Nurmukhambetov Zh.E. Records of the Persian leopard in the Republic of Kazakhstan. - Teriofauna of Russia and adjacent territories. International Meeting ( $X$ Congress of the Teriological Society of the Russian Academy of Sciences). Moscow, 2016: 325. (in Russian).]

Пфесффер Р.Г. О гнездовании чёрного грифа на юго-западном чинке Устюрта. - Казахстанский орнитологический бюметень 2005. Алматы: "Tethys", 2006. C. 189. [Pfeffer R.G. About nesting of the Eurasian Black Vulture on the south-western cliff-face of Usturt. - Kazakhstanian Ornithological Newsletter 2005. Almaty, 2006: 189. (in Russian).]

Скияренко С.А., Катцнер Т., Мак-Грэди М., Коваленко А.В. Грисра и сипа - в Красную Книгу. - Казахстанский орнитологический бюметень 2002. А^маты: «Tethys", 2002. С. 132-133. [Sklyarenko S.L., Katzner T., McGrady M., Kovalenko A.V. Eurasian Black Vulture and Griffon Vulture should be included in the Red Data Book. - Kazakhstanian Ornithological Newsletter 2002. Almaty, 2002: 132-133. (in Russian).]

Сиудский А.А., Асранасьев Ю.Г., Бекенов А., Грачёв Ю.А., Аобачев Ю.С., Махмутов С., Страутман Е.И., Федосенко А.К., Шубин И.Г. Миекопитаюшие Казахстана. Т. 3, ч. 2. Хишные (куньи, кошки). Аима-Ата: Наука, 1982. 264 c. [Sludsky A.A., Afanasyev Yu.G., Bekenov A., Grachev Yu.A., Lobachev Yu.S., Makhmutov S., Strautman E.I., Fedosenko AK, Shubin I.G. Mammals of Kazakhstan. Vol. 3, part 2. Predatory (Mustelids, Cats). AlmaAta, 1982: 1-264. (in Russian).]

BirdLife International. Aegypius monachus. The IUCN Red List of Threatened Spe- cies 2016: e.T22695231A90180020. 2016 a. DOI: 10.2305/IUCN.UK.2016-3.RLTS. T22695231A90180020.en. URL: http://www. iucnredlist.org/details/22695231/0 Date accessed: 20.03.2017.

BirdLife International. Gypaetus barbatus. The IUCN Red List of Threatened Species 2016: e.T22695174A90174498. 2016 b. DOI: 10.2305/IUCN.UK.2016-3.RLTS T22695174A90174498.en. URL: http://www. iucnredlist.org/details/22695174/0 Date accessed: 20.03.2017.

BirdLife International. Gyps fulvus. The IUCN Red List of Threatened Species 2016:e. T22695219A93497070. 2016 c. DOI: 10.2305/ IUCN.UK.2016-3.RLTS.T22695219A93497070. en. URL: http://www.iucnredlist.org/details/22695219/0 Date accessed: 20.03.2017.

BirdLife International. Gyps himalayensis. The IUCN Red List of Threatened Species 2016: e.T22695215A93496722. 2016 d. DOI: 10.2305/IUCN.UK.2016-3.RLTS. T22695215A93496722.en. URL: http://www. iucnredlist.org/details/22695215/0 Date accessed: 20.03.2017.

BirdLife International. Neophron percnopterus. The IUCN Red List of Threatened Species 2016: e.T22695180A90559652. 2016 e. DOI: 10.2305/IUCN.UK.2016-3.RLTS. T22695180A90559652.en. URL: http://www. iucnredlist.org/details/22695180/0 Date accessed: 20.03.2017.

Donбzar J.A., Cortes-Avizanda A., Carrete M. Dietary shifts in two vultures after the demise of supplementary feeding stations: consequences of the EU sanitary legislation. - European Journal of Wildlife Research. 2010. 56(4): 613-621. DOI: 10.1007/s10344-009-0358-0.

Jacobson A.P., Gerngross P., Lemeris J.R. Jr., Schoonover R.F., Anco C., Breitenmoser-Würsten C., Durant S.M., Farhadinia M.S., Henschel P., Kamler J.F., Laguardia A., Rostro-García S., Stein A.B., Dollar L., Leopard (Panthera pardus) status, distribution, and the research efforts across its range. - Peer]. 2016. 4:e1974; DOI: 10.7717/peerj.1974. URL: https://peerj.com/articles/1974 Date accessed: 20.03.2017.

Khorozyan I. Research and Conservation of the Persian Leopard (Panthera pardus saxicolor) in Bamu National Park, Faris Province, Iran. Yerevan, May 2008: 1-19. URL: http:// www.yemenileopard.org/files/cms/reports/Research_and_Conservation_of_the_Persian_Leopard_in_Bamu_National_Park.pdf Date accessed: 20.03.2017.

Oaks J.L., Gilbert M., Virani M.Z., Watson R.T., Meteyer C.U., Rideout B.A., Shivaprasad H.L., Ahmed Sh., Chaudhry M.J.I., Arshad M., Mahmood Sh., Ali A., Khan A.A. Diclofenac residues as the cause of vulture population decline in Pakistan. - Nature. 2004. 427(6975): 630-633. URL: http://www.nature.com/nature/journal/ v427/n6975/abs/nature02317.html Date accessed: 20.03.2017. 